\title{
Å vurdere yrkeskompetanse: Hva er yrkeskompetanse, og hvordan kan den vurderes?
}

\author{
(Evaluating vocational competence: \\ What is vocational competence, and how can it be evaluated?)
}

Hilde Hiim

OsloMet - Storbyuniversitetet, Norge (hhiim@oslomet.no)

\section{Abstract}

The aim of vocational education is that students develop initial vocational competence. However, what is vocational competence, and how can it be evaluated and assessed? In this article, questions of evaluating vocational competence are investigated from epistemological perspectives. First, I will examine definitions of competence in official documents and in research and look at research that can illuminate vocational competence and assessment in vocational education. Then, I will direct the focus towards epistemological perspectives on vocational competence and analyse what kind of implications the understanding of vocational competence has for curriculum and assessment. A main question is which forms of evaluation and assessment are relevant to stimulate and express students' development of vocational competence. Questions concerning the relationship between vocational competence, curriculum frameworks and forms of evaluation are analysed in light of rationalist, pragmatic and critical epistemology. I will argue that theoretical, practical and social aspects of vocational competence constitute a whole that also includes professional judgement, and that this must be expressed in the assessment. The article ends with a summary discussion of some important challenges and principles for relevant evaluation of vocational competence.

The article has its background in a Norwegian context of vocational education, but I think the analyses and discussions concern questions of general vocational pedagogical interest.

Keywords: evaluation, assessment, vocational knowledge, vocational competence, vocational education 


\section{Introduksjon}

I følge den norske opplæringsloven er formålet med vurdering "å fremme læring underveis og uttrykke kompetansen til eleven, lærlingen og lærekandidaten underveis og ved avslutningen av opplæringen" (\$3-2 Formålet med vurdering). Når det gjelder yrkesutdanning er det rimelig å tolke dette slik at det er elevens og lærlingens yrkeskompetanse som skal komme til uttrykk. Men det er ulike oppfatninger av hva yrkeskompetanse er og hvordan den utvikles.

I Meld. St. 28 (2015-2016, s. 28) er kompetanse definert slik: "Kompetanse er å tilegne seg og anvende kunnskaper og ferdigheter til å mestre utfordringer og løse oppgaver i kjente og ukjente sammenhenger og situasjoner. Kompetanse innebærer forståelse og evne til refleksjon og kritisk tenkning." Det står videre at "det å kunne anvende og vise hva man kan, er en viktig side ved kompetanse" (s. 29). Det blir dessuten framhevet at kompetanse forutsetter emosjonell læring.

I en artikkel basert på en omfattende studie av kompetansebegrepet i høyere yrkesutdanning blir kompetanse definert som: "et integrert sett av kunnskaper, ferdigheter og holdninger" (Koenen, Dochy \& Berghmans, 2015, s. 2). Det blir imidlertid framhevet både i denne og andre artikler at kompetansebegrepet ofte brukes både ulikt og uklart (Lester \& Religa, 2017). Det er likevel tre elementer som inngår i de fleste definisjonene: kunnskaper, ferdigheter og (dels) holdninger utgjør en helhet, det handler om å kunne løse oppgaver, og kompetansen skal kunne demonstreres og eventuelt måles. Koenen m.fl. (2015) presiserer videre i sin artikkel at kompetansebasert yrkesutdanning er en utdanning hvor autentisk oppgave- og problemløsning, fagintegrering og teori knyttet til oppgavene er hovedprinsipper. De framhever også at det er svært ulikt $i$ hvor stor grad disse prinsippene blir realisert i yrkesutdanningene.

Jeg vil i fortsettelsen først se nærmere på forskning som kan belyse yrkeskompetanse og vurdering, knyttet til spørsmål om helhet og sammenheng i yrkesutdanningen. Deretter vil jeg analysere hva yrkeskompetanse består i og hvordan den kan utvikles og vurderes, ut fra rasjonalistiske, pragmatiske og kritiske epistemologiske perspektiver.

\section{Forskning som belyser yrkeskompetanse og vurdering}

Mye internasjonal forskning på yrkesutdanning har i de siste årene rettet søkelyset mot behovet for å utvikle tilnærminger som bygger på en flerdimensjonal og helhetlig oppfatning av yrkeskompetanse, hvor både forståelse og utøvelse inngår. Det blir lagt vekt på sammenheng mellom teori og praksis og mellom læringsarenaer. Begreper som innovasjonspedagogikk, design-pedagogikk og hybrid læring dreier seg om tilnærminger til yrkesutdanning som legger vekt på å utvikle helhetlig yrkeskompetanse gjennom nærhet mellom skole og arbeidsliv, nærhet til yrkesoppgavene og tverrfaglig utdanningsinnhold med klar betydning 
for yrkesutøvelsen (Cremers, Wals, Wesslink \& Mulder, 2016; Kairisto-Merkanen, Rasanen, Lehtonen \& Lapalainen, 2012; Zitter, Hoeve \& de Bruijn, 2016).

I flere yrkesutdanninger, ikke minst i tysk yrkesutdanning, er det utviklet vurderingsmodeller som tar utgangspunkt i at yrkeskompetanse er holistisk og handlingsrettet. Modellene har utarbeidet systemer for å analysere og vurdere yrkeskompetanse ut fra sammenliknbare, graderte kategorier (Rauner, 2007; Rein, 2017). Prøveformen omhandler autentiske, praktiske oppgaver i f.eks. elektrikerfaget. Et spørsmål knyttet til slike vurderingsmodeller er hvordan forholdet mellom praktisk utførelse og skriftlig dokumentasjon kan tilrettelegges når hensikten er å vurdere helhetlig yrkeskompetanse (Hiim, 2013). I forbindelse med en undersøkelse om vurdering i svensk yrkesutdanning blir det dessuten stilt spørsmål ved hvorvidt systemer for sammenlikning og gradering av elevenes læring er relevant når det gjelder den personlige, sosiale evnen til å møte mennesker som er en grunnleggende del av kompetansen i sosiale yrker som f.eks. barn- og ungdomsarbeidere eller helsefagarbeidere (Johansson \& Thång, 2017).

Forskning på norsk yrkesutdanning peker mot at eksisterende læreplaner og vurderingsformer innebærer utfordringer når det gjelder elevenes muligheter for å utvikle helhetlig yrkeskompetanse (Aakernes, 2018; Bødker-Lund, Hansen, Haaland \& Vagle, 2017; Hiim, 2013, 2015; Sylte, 2014). Selve utdanningsstrukturen - to år i skole fulgt av to år som lærling i bedrift - peker i seg selv til dels mot et skille mellom teoretisk undervisning på skolen og praktisk opplæring i bedrift. Læreplanene for både skole- og bedriftsdelen er i prinsippet forsøkt innrettet mot yrkesoppgaver, men fortsatt er det i mange yrkesfaglige utdanningsprogram i stor grad et skille mellom læreplanmål som gjelder praktisk utøvelse og rene teorimål. Planene er dessuten preget av stor grad av inndeling i skolefag som skal ha separat vurdering og karakter (Utdanningsdirektoratet, 2006). Inndelingen i fag med egen karakter og i teori og praksis gjør kompetansebasert, helhetlig utdanning, slik det er definert av Koenen m.fl. (2015) ovenfor, vanskelig (Hiim, 2013).

I internasjonal forskning på yrkesutdanning kommer det fram tilsvarende problemer. Forsøkene med å utvikle mer helhetlige tilnærminger til yrkesopplæring og vurdering som er nevnt ovenfor, har til dels bakgrunn i at opplæringen i utgangspunktet ofte har vært fragmentert. Den har vært preget av skiller mellom læringsarenaer, særlig mellom praktisk opplæring i bedrift og teoretisk undervisning på skole, og mellom skolefag som i liten grad blir integrert og relatert til utøvelsen av yrket. Slike skiller har en tendens til å medføre mangel på sammenheng mellom yrkesinnhold og utdanningsinnhold. Selv om utdanningsmodellene er ulike, er dette utfordringer som i ulike varianter går igjen på tvers av land og modeller (Gessler, 2017; Louw, 2017; Wahlgren \& Aarkrog, 2012; Young, 2004). Et viktig spørsmål er hva som er bakgrunnen for disse utfordringene, og hvilken sammenheng de kan ha med forståelsen av yrkeskompetanse. 


\section{Epistemologiske perspektiver på yrkeskompetanse og vurdering}

På 1980- og 90-tallet oppsto det diskusjoner omkring yrkes- og profesjonsutdanning som hadde grunnlag i epistemologiske undersøkelser av hva yrkeskompetanse består i, og det ble utviklet teorier som omhandlet prinsipper i yrkes- og profesjonsutdanning (Dreyfus \& Dreyfus, 1986; Hiim \& Hippe, 2001; Janik, 1996; Josefson, 1991; Molander, 1997; Schøn, 1983, 1988, 1995; Stenhouse, 1975, 1983). Et viktig grunnlag var bl.a. pragmatisk orienterte tolkninger av Wittgensteins (2003) sene og Heideggers (1978) tidlige filosofi, analyser av kritisk filosofi, særlig Habermas (1999), og kritikk av en ensidig rasjonalistisk, teknisk forståelse av yrkeskompetanse. Det ble stilt spørsmål ved hvorvidt innholdet i yrkes- og profesjonsutdanning er tilstrekkelig relevant for å utvikle yrkeskompetanse, og om vurderingsformene bidrar til å fremme og uttrykke slik kompetanse.

Jeg vil i fortsettelsen gjøre en sammenliknende analyse av noen sentrale epistemologiske perspektiver og teorier, rettet mot å belyse vurdering av yrkeskompetanse i dagens yrkesutdanning. Jeg vil først presentere en rasjonalistisk, teknologisk orientert tilnærming til yrkeskompetanse, læreplaner og vurdering som i de siste par tiårene har fått fornyet innflytelse innenfor nyliberalistisk utdanningsideologi. Deretter vil jeg undersøke hvilken betydning noen sentrale epistemologiske perspektiver hos Wittgenstein (2003) og Heidegger (1978) kan ha for forståelsen av yrkeskompetanse og vurdering, og hvilken sammenheng disse perspektivene har med begreper om yrkeskompetanse og vurdering hos Dreyfus og Dreyfus (1986) og Schøn $(1983,1988,1995)$. Så vil jeg undersøke yrkeskompetanse og vurdering i lys av kritisk teori (Habermas, 1999). Ulike epistemologiske perspektiver på vurdering av yrkeskompetanse blir sammenfattet i en oppsummerende diskusjon av sentrale utfordringer og prinsipper.

\section{En rasjonalistisk, teknisk tilnærming til yrkeskompetanse, læreplaner og vurdering}

\section{Et rasjonalistisk, teknisk begrep om kompetanse}

Et rasjonalistisk, teknisk orientert kompetansebegrep har røtter tilbake til positivismen, og har i ulike perioder vært dominerende i utdanningssystemet, også i yrkesutdanningen (Schøn, 1983; Stenhouse, 1975). Kognitiv kunnskap blir ansett som en form for mental avbildning av objektive, gitte enheter i en ytre verden som står i et lovmessig forhold til hverandre. Avbildningene kan uttrykkes og overføres gjennom verbaliserte begreper (Molander, 1997). En rasjonalistisk, teknisk orientert forståelse av yrkeskompetanse innebærer at forholdet mellom verbaliserte begreper - teori, og handling i yrkesfeltet - praksis, til dels blir ansett som et slags en-til-en-forhold (Molander, 1997; Schøn, 1983). Dette vil i prinsippet 
si at teori kan læres først, og at profesjonell praksis i stor grad dreier seg om å anvende teori.

Et rasjonalistisk oppfatning av forholdet mellom teori og praksis vil også prege forståelsen av forholdet mellom begrepene "kunnskaper", "ferdigheter" og "holdninger" (Hiim, 2010). Kunnskap dreier seg om det som kan verbaliseres gjennom en form for teori, mens ferdigheter handler om det utøvelsesmessige og motoriske. Holdninger omhandler på sin side yrkesetiske verdier og arbeidsmoral. Begrepet "yrkeskompetanse" kan som nevnt oppfattes som et forsøk på å innlemme kunnskaper, ferdigheter og holdninger i ett felles begrep. Sett fra et rasjonalistisk perspektiv er imidlertid forholdet mellom elementer i yrkeskompetanse - mellom teoretiske kunnskaper og praktiske ferdigheter - relativt symmetrisk. Teorien angir prosedyrer og begrunnelser for praktisk utøvelse. Kompetanse dreier seg om å kunne redegjøre for og demonstrere utøvelse av prosedyrer, og om å kunne begrunne utøvelsen.

En rasjonalistisk forståelse av yrkeskompetanse har en tendens til å innebære at det blir lagt vekt på å standardisere lærings- og arbeidsprosesser og -resultater. Standardiseringen kommer bl.a. til uttrykk gjennom utarbeiding av presise verbale beskrivelser og målbare kriterier for læringsutbytte og kvalifisert yrkesutøvelse. Hensikten er at beskrivelsene skal fungere som en form for prosedyrer for lærings- og arbeidsprosessen. De skal også utgjøre et grunnlag for å måle og sammenlikne lærings- og arbeidsresultater (Hiim, 2013).

\section{Et rasjonalistisk, teknisk perspektiv på læreplaner og vurdering}

En rasjonalistisk, teknisk tilnærming til yrkeskompetanse kan i noen tilfeller ha en tendens til å innebære at læreplanmål og vurderingskriterier er preget av inndeling mellom teoretisk kunnskap og praktiske ferdigheter. Valg av faglig innhold og læringsoppgaver blir oppfattet som en ytterligere operasjonalisering av læreplanmålene, og viderefører dermed ofte en inndeling mellom teori og praksis.

F.eks. i norske læreplaner fram til 2006 omhandlet mål og vurderingskriterier for de to første, skolebaserte årene av yrkesutdanningen i hovedsak teoretiske kunnskaper. Målene var preget av detaljerte formuleringer om hva elevene skulle "kunne gjøre greie for", "kunne drøfte", osv. Mål og kriterier for de to siste, arbeidslivsbaserte årene som lærling omhandlet i hovedsak detaljerte praktiske ferdigheter, med formuleringer om hva elevene skulle "kunne utføre". Skillet mellom teoretiske kunnskaper og praktiske ferdigheter skapte utfordringer i forhold til helhet og sammenheng i yrkesutdanningen (Hiim, 2013).

Fra et rasjonalistisk, teknisk orientert perspektiv på yrkeskompetanse vil det bli lagt vekt på å utvikle læreplaner og vurderingskriterier som gir et godt grunnlag for måling og kontroll av elevenes læringsprosess og -resultat. Det vil også være ønskelig å utvikle standardiserte kompetansebeskrivelser for det enkelte yrke som presist og relativt detaljert setter ord på hva en godt kvalifisert 
yrkesutøver må kunne. På 1980-tallet ble det satt i gang en rekke forsøk med å utvikle standardiserte beskrivelser av yrkes- og profesjonsutøvelse og kompetansekrav i ulike yrker. Hensikten var å gi en oversikt over hva yrkesutøvelsen består i, og hva slags oppgaver og funksjoner det forventes at yrkesutøveren kan mestre. Beskrivelsene skulle gi grunnlag både for opplæring og vurdering av yrkesutøveres kompetanse (Dreyfus \& Dreyfus, 1986; Josefson, 1991). Hensikten var å oppnå bedre sammenlikningsgrunnlag og større kontroll over yrkes- og profesjonsutøveres kvalifikasjoner. Slike kompetansebeskrivelser ble også utviklet som en del av arbeidet med læreplanene for yrkesfag i Kunnskapsløftet i 2006 (Meld. St. 30, 2003-2004).

Et viktig argument i utviklingen av kompetansebeskrivelser har vært at de gjør det mulig å samordne yrkesutdanningen på tvers av land og utvikle felles vurderingssystemer som kan styre innhold og oppgaver på utdanningsinstitusjoner og i lærebedrifter (NOU 2008:18). Det er blitt gjort ulike typer forsøk og erfaringer med dette, bl.a. i forbindelse med utvikling av et felles europeisk kvalitetsvurderingssystem for yrkesutdanning - ECVET (Larsen, 2013; Utdanningsdirektoratet, 2013). Det kan imidlertid være utfordrende å komme fram til felles kompetanse- og læringsutbyttebeskrivelser bl.a. fordi tradisjoner og krav til utøvelse i et yrke kan variere mye mellom land og yrkeskulturer.

Den nåværende norske malen for læringsutbyttebeskrivelser i høyere utdanning fra bachelornivå, inkludert høyere yrkes- og profesjonsutdanning, er strukturert i kategorier som omhandler henholdsvis kunnskaper, ferdigheter og generell kompetanse (Meld. St. 9, 2016-2017; Meld. St. 16, 2016-2017). Det kan diskuteres om denne kategoriseringen er hensiktsmessig når det gjelder utvikling og vurdering av yrkeskompetanse, eller om den kan bidra til å opprettholde og forsterke et skille mellom teori og praksis som skaper problemer i yrkesutdanningen. Jeg skal komme mer inn på dette spørsmålet i den videre diskusjonen.

Nyliberalistiske oppfatninger av utdanning har til dels vært preget av et rasjonalistisk, teknisk perspektiv på yrkeskompetanse og -utdanning. Det blir lagt vekt på at kompetanse og arbeid kan anses som en vare som bør kunne flyte fritt mellom markeder i vårt globaliserte samfunn (Davies \& Bansel, 2007). Når kompetanse blir en vare som skal kunne prisfastsettes, konkurranseutsettes og utveksles, er det en tendens til at fokuset på kvantitative aspekter som handler om standardisering, måling og kontroll øker (Bottery, 2006). Det blir lagt vekt på å utvikle objektive, forhåndsdefinerte kriterier for kompetanse på ulike nivå som kan gi grunnlag for måling, vurdering, rapportering og sammenlikning på tvers av utdanningssystemer og land (Young, 2007). Stadig større utbredelse av datateknologi medfører at denne formen for objektivisering og måling av kompetanse blir enklere å gjennomføre, og kan i seg selv bidra til å styrke en rasjonalistisk, teknisk orientert oppfatning av hva kompetanse er og av hva som skal vurderes (Dreyfus \& Dreyfus, 1986). I omtalen av definisjonen av kompetanse i 
Meld. St. 28 (2015-2016) som det er vist til ovenfor, blir det presisert at kompetanse skal kunne demonstreres og eventuelt måles.

Bruken av kompetansebegrepet i nåværende norsk og internasjonal utdanning kan anses for å ha en viss tilknytning både til nyliberalismen og til diskusjoner om kvalitet i yrkes- og profesjonsutdanning de siste tiårene. Begrepet ble i mindre grad brukt i læreplaner og i pedagogikken før 1990- tallet. Det var mer vanlig å bruke betegnelser som kunnskaper, ferdigheter og holdninger, kunnskapsfag og ferdighetsfag, og teoretiske og praktiske fag. Kompetansebegrepet slik det defineres i dag kan oppfattes som et forsøk på å skape et helhetlig og samtidig flerdimensjonalt begrep som samtidig omfatter målbarhet.

Kritikk av et rasjonalistisk, teknisk perspektiv på yrkeskompetanse, læreplaner og vurdering

Et ensidig rasjonalistisk, teknisk begrep om yrkeskompetanse er blitt utsatt for kritikk (Billett, 2011; Dreyfus \& Dreyfus, 1986; Hiim, 2010, 2013; Molander, 1997; Schøn, 1983; Young, 2004, 2007). Det blir bl.a. påpekt at forståelsen av forholdet mellom praksis og teori er for enkel og kan bidra til å opprettholde en uheldig inndeling mellom teoretiske og praktiske fag og læringsarenaer. En slik inndeling vil også medføre at teoretisk kunnskap og praktisk utøvelse blir vurdert hver for seg. Sterk standardisering av yrkeskompetanse og mål for opplæring kan dessuten komme til å medføre mangel på muligheter til å utøve og utvikle profesjonelt skjønn. Lester og Religa (2017) konkluderer f.eks. i sin sammenliknende analyse av vurderingssystemer med at mye tyder på at for standardiserte og presise kompetansekriterier er uheldig og hemmer utvikling.

\section{En pragmatisk tilnærming til yrkeskompetanse, læreplaner og vurdering}

Jeg vil i fortsettelsen først undersøke perspektiver på yrkeskompetanse og vurdering i lys av henholdsvis Wittgensteins (2003) spillmetafor og Heideggers (1978) verkstedmetafor for erfaring, deretter ut fra Dreyfus og Dereyfus (1986) og Schøn $(1983,1988)$ sine epistemologiske perspektiver og teorier. En kjerne dreier seg om den menneskelige erfaringens helhetlige karakter og nødvendigheten av å lære gjennom deltakelse i praksiser.

\section{Utvikling av yrkeskompetanse i lys av Wittgensteins spillmetafor}

Wittgensteins (2003) spillmetafor presenterer menneskelig erfaring som levende, lekende aktivitet. Våre handlinger og bruken av ord og begreper er vevd inn i eksisterende livsformer, kulturelle mønstre og kontekster. Meningen av ord og handlinger avhenger av og blir klar gjennom konteksten. En bremsepedal er bare en bremsepedal i kombinasjon med hele mekanismen, en sjakkbrikke får mening 
fra sjakkspillet. Wittgensteins helhetlige oppfatning av erfaring, begreper og språk peker mot nødvendigheten av å lære gjennom eksempler og gjennom å delta i kontekster og praksiser som handlinger, begreper og ord har mening i. Det er nødvendig å delta i f.eks. "elektrikerspillet" eller "helsefagarbeiderspillet" for å lære hva yrket dreier seg om, hva som er hensikten og hva grunnleggende oppgaver og begreper består i. Situasjonen og konteksten er den sentrale meningsenheten. Nødvendigheten av å lære gjennom deltakelse og eksempler skyldes ikke mangel på generelle forklaringer. Generalisering medfører et meningstap (Dreyfus, 1991). Eksemplenes rolle er å vise variasjon og mangfold i f.eks. utøvelsen av oppgavene som elektriker eller helsefagarbeider.

Det er imidlertid behov for eksempler som viser profesjonelle handlingsmønstre eller paradigmatiske handlinger i det aktuelle yrket eller profesjonen (Janik, 1996). Paradigmatisk handling dreier seg om vesentlige oppgaver i yrket. Å lære et sentralt begrep dreier seg om å lære en paradigmatisk handling. Bruk av yrkesbegreper og yrkeshandlinger innebærer å utvise dømmekraft i konkrete situasjoner, og å kunne se og ta hensyn til likheter og ulikheter. Bruk av begreper har sett ut fra Wittgenstein både sanselige, kroppslige, følelsesmessige og intellektuelle aspekter, og krever øvelse. Læring dreier seg om å utvikle fortrolighet med begreper og handle i meningsfylte kontekster, og bruke relevante ord og fagspråk, som f.eks. elektriker eller helsefagarbeider.

Det Janik (1996) i sin tolkning av Wittgenstein kaller "praktisk kunnskap", som i denne sammenhengen kan sidestilles med yrkeskompetanse, handler ikke om å anvende verbaliserte teorier i partikulære situasjoner. Yrkeskompetanse kan ifølge Janik ikke utvikles gjennom å tilpasse generelle regler til spesielle tilfeller. Yrkeskompetanse genereres gjennom dømmekraft knyttet til eksempler, og gjennom å oppdage meningsfylte likheter og ulikheter i f.eks. utøvelsen av elektrikeroppgavene. Det er dessuten nødvendig å bli vist og å reflektere sammen med kolleger som har erfaring og behersker det aktuelle «spillet» eller praksisen - ingen kan lære en praksis alene.

Involvering, sensibilitet og instinkt er i lys av Wittgenstein like viktig som intellektuell og teoretisk forståelse. Yrkeskompetanse og dømmekraft er fra et pragmatisk perspektiv i kroppen, i motorikken, i hva vi ser og oppfatter, i følelsesmessig involvering og i yrkeskulturen. Den er holistisk og flerdimensjonal, og kommer fram gjennom holistiske og flerdimensjonale uttrykksformer.

Yrkeskompetansens helhetlige og flerdimensjonale karakter må ut fra dette perspektivet ivaretas i læreplanene og i vurderingen.

\section{Utvikling av yrkeskompetanse i lys av Heideggers verkstedmetafor}

Heidegger (1978) avviser i likhet med Wittgenstein ideer om verbalisert kunnskap som en avspeiling av verden. Kompetanse kan i lys av Heidegger anses som uløselig knyttet til menneskets væremåte i verden. Heidegger bruker en verkstedmetafor for menneskelig erfaring. Begreper læres gjennom vår interaksjon 
med ting. Vi lærer f.eks. hva en hammer er gjennom å bruke den. Hammerens egenskaper har mening gjennom dens funksjon og hensikt i verkstedet, f.eks. å snekre møbler til hus som folk skal leve i. Bruk av ting og begreper har alltid grunnlag i hensikter, funksjoner og kontekster som allerede er der i vår eksistens og kultur. Det er ingen teori "bak" våre dagligdagse handlinger (Dreyfus, 1991). $\AA$ vite hvordan er grunnleggende, å vite at er sekundært. Handlinger kan forstyrres av problemer - hammeren er f.eks. for tung, eller en pasient ser urolig og blek ut. Man får en mer eksplisitt forståelse av f.eks. hammeren og dens egenskaper eller av pasientens tilstand.

Vekstedmetaforen peker mot at situasjoner og kontekster er grunnlag for læring og utvikling av kompetanse. Partikulære handlinger og begreper får mening gjennom meningsfylte kontekster, situasjoner og sammenhenger som vi er involvert i (Dreyfus, 1991). Vi reflekterer ikke over alle sider ved arbeidet vårt, men over utfordringer, f.eks. en pasient som ser urolig og blek ut. Menneskets verden kan anses som en handlings- og meningssammenheng, som et verksted hvor alt har en hensikt. I lys av verkstedmetaforen forutsetter utvikling av profesjonell kompetanse deltakelse i sentrale oppgaver og eksempler, og kommer til uttrykk gjennom utførelse av oppgavene.

Heidegger (1978) framhever at vår eksistens er konstituert av følelser, forståelse og absorbert handling som en helhet. Stemninger og emosjonell atmosfære, som har både kulturelle og individuelle aspekter, avgjør hva som eksistensielt åpner seg i tid og rom. For Heidegger handler forståelse primært om å vite hvordan og kunne utøve - å forstå seg på seg på f.eks. tømring dreier seg primært om å kunne tømre, ikke om å kjenne til hammerens ulike fysiske egenskaper. $\AA$ kunne og forstå hvordan er mer grunnleggende enn et skille mellom handling og tanke. Dreyfus (1991) framhever i sin tolkning av Heidegger at profesjonelt utført praksis ikke nødvendigvis innebærer kontinuerlig planlegging, men kan være preget av absorbert og intuitiv handling. Det som skjer i prosessen avgjør hva som anses som viktig og hva som må overveies.

Yrkeskompetanse handler fra et Heidegger - inspirert perspektiv primært om å kunne utføre oppgavene i det aktuelle yrket på en profesjonell måte, og om å kunne møte nye og ulike utfordringer profesjonelt. Evne til profesjonell utøvelse er fra et pragmatisk perspektiv i en viss forstand "overordnet" generell teoretisk kunnskap, selv om profesjoner og yrker selvsagt har behov for å utvikle ulike typer teoretiske perspektiver og begrunnelser (Dreyfus, 1991). Molander (1997) framhever at det i mye læringsteori og i utdanningssystemet er en tendens til å oppfatte generell, abstrakt kunnskap som "overordnet", og at dette kan skape problemer i yrkes- og profesjonsutdanningene. Det kan bl.a. føre til at det blir lagt uforholdsmessig vekt på løsrevne, generelle teorikunnskaper både i læreplaner og i vurderingen. 
En pragmatisk tilnærming til læreplaner og vurdering

Både Dreyfus og Dreyfus $(1986)$ og Schøn $(1983,1988)$ legger sterk vekt på yrkeskompetansens kontekstuelle og holistiske karakter, og på læring og kompetanseutvikling gjennom deltakelse i praktiske yrkesoppgaver. Det er slik sett en betydelig sammenheng mellom deres syn på yrkeskompetanse og pragmatiske tolkninger av Wittgenstein og Heidegger, som de også er inspirert av (Hiim, 2013). Deres arbeider omhandler tilnærminger til helhetlig profesjons- og yrkesutdanning. For å framheve helheten, benytter Schøn begrepene "knowing-in-action", som Molander (1993) kaller kunnskap-i-handling, og refleksjon-i-handling. Dreyfus og Dreyfus bruker begrepet "skills" om kompetanse på ulike nivå, og "expertice" om kompetanse på høyeste nivå. Begge er opptatt av at yrkeskompetanse er helhetlig og flerdimensjonal og primært kommer til uttrykk gjennom utøvelse, sammen med verbaliserte begreper og begrunnelser. De legger vekt på læring og kompetanseutvikling gjennom praktiske eksempler, oppgaver, utfordringer og refleksjon. Med dette som utgangspunkt har både Dreyfus og Dreyfus (1986) og Schøn $(1983,1988)$ utarbeidet sentrale prinsipper for yrkes- og profesjonsutdanning som også har betydning for vurdering. Også Hiim og Hippe (2001) har utarbeidet slike prinsipper, basert på bl.a. inspirasjon fra tolkninger av Wittgenstein og Heidegger (Hiim, 2013).

Det er for det første behov for at læreplanen sier noe om yrkets samfunnsmandat på en slik måte at det hjelper elevene til å forstå den grunnleggende hensikten med yrket de utdanner seg til og hvilke samfunnsmessige forpliktelser det dreier seg om (Hiim, 2013). Fra et pragmatisk perspektiv er det vesentlig at læreplanen, som også angir grunnlaget for vurdering, bidrar til å ivareta og gi uttrykk for yrkeskompetansens helhetlige karakter, og ikke splitter utdanningen unødig opp i teoretiske og praktiske fag. Læreplanene bør derfor struktureres omkring sentrale yrkesoppgaver eller yrkesfunksjoner i det aktuelle yrket/yrkene. Rauner (2007) framhever at å strukturere innholdet i yrkesopplæring omkring yrkesfunksjoner innebærer en annen og mer helhetlig forståelse av yrkeskompetanse enn det å strukturere opplæringen omkring fag. Både Dreyfus og Dreyfus (1986) og Schøn (1988) legger vekt på at utdanningsinnholdet er helhetlig og integrert omkring yrkesoppgaver, snarere enn oppdelt i separate skolefag. Vurderingskriterier som kommer til uttrykk gjennom læreplanmålene skal fra et pragmatisk perspektiv si noe om hvilke sentrale yrkesoppgaver elever og lærlinger skal kunne beherske i ulike faser av utdanningen.

Dreyfus og Dreyfus (1986) legger vekt på at oppgaver og eksempler som inngår i profesjons- og yrkesutdanning ikke er for strukturerte og entydige. Elever og lærlinger trenger å utvikle kompetanse i å identifisere og tolke utfordringer i yrket, noe som også vil være et relevant kriterium i vurderingen. Tilstrekkelig variasjon mellom oppgavene er dessuten nødvendig for å oppdage og kunne bedømme vesentlige likheter og ulikheter mellom situasjoner. Teori 
handler for Dreyfus og Dreyfus primært om perspektiver på og begrunnelser for de aktuelle oppgavene.

Vurderingsgrunnlaget er med dette utgangspunktet elever og lærlingers planlegging, gjennomføring, begrunnelse for og vurdering av sentrale oppgaver og funksjoner i det aktuelle yrket. Progresjon handler ifølge Dreyfus og Dreyfus om systematisk økende kompleksitet i oppgavene og økende grad av involvering og ansvar som gjenspeiler en utvikling fra novise til ekspert. Et hovedkriterium i vurdering av ferdig utdannede yrkesutøvere er hvorvidt de behersker relativt komplekse oppgaver på en selvstendig måte og viser forståelse for sitt samfunnsansvar.

Schøn $(1983,1988)$ deler mange av Dreyfus og Dreyfus sine prinsipper, men framhever særlig betydningen av refleksjon. Han legger stor vekt på det han kaller et reflekterende praktikum eller et verksted der elever og lærlinger kan prøve og feile under trygge forhold og kyndig veiledning. Kriterier for vurdering vil være at eleven eller lærlingen viser evne til å reflektere over aktuelle oppgaver, til å tilpasse løsningen til den aktuelle situasjonen og evne til å lære av praksis. Schøn er opptatt av at yrkesutøvere utvikler en forskerinnstilling til praksis, og vurderingen kan bidra til dette gjennom å legge vekt på utvikling og kreativitet. Yrkesutøvere som systematisk lærer av og utforsker praksis kan bidra til å styrke utvikling av kompetanse på høyere nivå innen det enkelte yrke.

Ut fra både Schøn og Dreyfus og Dreyfus er det et hovedpoeng at eksempler og oppgaver som inngår i opplæringen og blir vurdert ikke er for strukturerte og standardiserte. Argumentet er at standardisert vurdering vil ha en tendens til å konservere yrkesutøvelsen i gitte løsninger og hindre utvikling. Svært presise vurderingskriterier knyttet til gradert måling av elevers og lærlingers kompetanse kan også komme til å virke uheldig, fordi det kan medføre ytterligere standardisering og hindre forståelsen av at det kan være flere ulike og gode måter å løse en oppgave på.

Ut fra et holistisk, flerdimensjonalt syn på yrkeskompetanse vil det bli lagt vekt på å kombinere ulike uttrykksformer i vurderingen. Vurdering som innebærer praktisk utøvelse, begrunnelse, drøfting og refleksjon er det viktigste, men bruk av f.eks. ulike former for billedmateriale, modeller, visning av produkter, osv. kan også bidra til å gi uttrykk for yrkeskompetansen på en hensiktsmessig måte. Hovedprinsippet er at yrkeskompetansens helhetlige karakter blir ivaretatt, og at oppgaver og eksempler som velges ut til formell vurdering er sentrale og relevante for det aktuelle yrket.

\section{Kritikk av et pragmatisk perspektiv på yrkeskompetanse, læreplaner og vurdering}

Et pragmatisk epistemologisk perspektiv er blitt kritisert for å legge for ensidig vekt på eksisterende praksistradisjoner, og for lite vekt på sosial endring og utvikling (Habermas, 1980). I moderne yrker er det dessuten behov for å rette 
oppmerksomheten mot den raske teknologiske utviklingen og mot elever og lærlingers kompetanse i forhold til å holde seg oppdatert, noe som også bør komme til uttrykk i vurderingen. Den teknologiske utviklingen kan også medføre betydelige endringer i arbeidets sosiale organisering som det er viktig at profesjonelle yrkesutøvere har et reflektert og kritisk forhold til. Det kan stilles spørsmål om hvorvidt et pragmatisk perspektiv på yrkeskompetanse i tilstrekkelig grad omfatter et samfunns- og organisasjonsperspektiv (Nielsen, Nielsen, Munk-Madsen \& Hartmann-Petersen, 2010). En annen innvending er at det et betydelig behov for mer inngående analyser av og eksempler på hvordan praktiske oppgaver og teoretiske begrunnelser kan henge sammen og hvordan helheten kan vurderes, både generelt og innen det enkelte yrke. Dette er som nevnt innledningsvis et viktig tema innen nyere forskning på yrkesutdanning (Heusdens, Bakker, Baartman \& de Bruijn, 2016).

\section{En kritisk tilnærming til yrkeskunnskap, læreplaner og vurdering}

\section{Et kritisk perspektiv på yrkeskompetanse}

Habermas' (1999) teori om kommunikativ handling kan bidra til å belyse vesentlige sider ved yrkeskompetanse og vurdering. Et hovedanliggende i teorien er å skape et grunnlag for sosial kritikk og utvikling gjennom kritisk kommunikativ kompetanse. For Habermas er det viktig at alle borgere i et samfunn utvikler slik kompetanse. Kritisk kommunikativ kompetanse handler om å kunne vurdere ytringer og handlinger ut fra grunnleggende gyldighetskrav som også har betydning i forhold til profesjonell yrkesutøvelse.

Ulike typer gyldighet eller validitet er for Habermas relatert til fire ulike typer handling - instrumentell handling, konversasjon, dramaturgisk handling og normregulert handling. Instrumentell handling er mål- og resultatorientert, og gyldighetskravet er at handlingen er effektiv. Konversasjon er forståelsesorientert, og gyldighetskravet er om det som påstås er objektivt sant. Dramaturgisk handling dreier seg om å gi uttrykk for følelser og meninger, og gyldighetskravet er om det er subjektivt oppriktig. Normregulert handling dreier seg om hvorvidt det som sies og gjøres er rettferdig og riktig ut fra sosiale verdier.

Habermas (1999) framhever at det er tendenser i moderne samfunn til å redusere handlinger, også yrkeshandlinger, til et spørsmål om effektivitet. Fra et instrumentelt perspektiv vil yrkesutøvelse, yrkesutdanning og yrkeskompetanse primært bli vurdert ut fra effektivitet. Prinsippet om effektivitet blir iverksatt i form av standardisering, måling, sammenlikning og konkurranse. Sett fra Habermas' perspektiv er effektivitet et vesentlig gyldighetskrav, men det er problematisk når det blir ensidig og dominerende. For det første kan standardisering medføre at yrkesutøvelsen i stor grad blir styrt utenfra gjennom detaljerte anvisninger. I dag er det blitt vanlig at slike anvisninger også gis digitalt av 
datamaskiner og roboter. Når fagarbeidere blir styrt utenfra og vurdert ensidig ut fra effektivitetskrav kan det medføre stress, stagnasjon av yrkeskompetansen og tap av yrkesstolthet (Nielsen m.fl., 2010; Sennet, 2008). Ensidig fokus på resultatmåling, effektivitet og konkurranse i elevens utvikling av yrkeskompetanse kan også medføre at elevens selvbilde blir skadelidende.

Yrkeskompetanse handler fra et kritisk perspektiv også om kulturelle verdier og normer knyttet til samfunnsoppdraget. Et viktig kriterium i utøvelsen av oppgaver som f.eks. helsefagarbeider eller tømrer er at den samsvarer med både det enkelte yrkets og samfunnets verdier om hva som er riktig og rettferdig. Et annet kriterium er hvorvidt arbeidet som blir gjort er forståelig for involverte parter. Sosiale og verdimessige aspekter ved yrkeskompetanse er relatert til demokratiforståelse og forståelse av grunnleggende menneskerettigheter. Profesjonelle yrkesutøvere - tømrere eller helsefagarbeidere - må utvikle kritisk kommunikativ kompetanse, som dreier seg om å kunne forstå og samarbeide med andre, bevissthet om sosiale og etiske verdier og evne til å bidra til faglig og demokratisk utvikling.

For å gi elever og lærlinger muligheter for å utvikle kritisk kommunikativ kompetanse, er det en forutsetning at selve utdanningsprosessen har utgangspunkt i en kritisk tilnærming. Yrkesutdanning må forstås som en sosial danningsprosess, hvor elever og lærlinger skal utvikle seg som yrkesutøvere både teknisk, sosialt og moralsk, og kunne bidra til demokratisk samarbeid og utvikling. Dette kan oppnås gjennom en utdanning hvor undervisning, læring og arbeid forløpende blir vurdert av lærere, elever, instruktører og lærlinger ut fra følgende kriterier: Er det som skjer i prosessen effektivt og i tråd med aktuell sakkunnskap? Er det forståelig for alle som er involvert? Har alle som er involvert muligheter for å uttrykke seg oppriktig om det som blir sagt og gjort? Er det som skjer rettferdig? En kritisk forståelse av yrkeskompetanse stiller krav om stor grad av medvirkning i utdannings-, arbeids- og vurderingsprosessen.

\section{Et kritisk perspektiv på læreplaner og vurdering}

Fra et kritisk perspektiv vil en være skeptisk til sentralgitte læreplaner og målformuleringer som ensidig bygger på prinsipper om standardiserte arbeidsbeskrivelser eller detaljerte beskrivelser av læringsutbytte. Argumentasjonen er at høy grad av standardisering ikke gir tilstrekkelig rom for lokal medvirkning. Sett fra et kritisk utgangspunkt må mål og vurderingskriterier være tilstrekkelig vidt definert til å gi frihet til selvstendig utforming av arbeids- og læreprosesser. De må også gjenspeile sentrale samfunnsverdier som er blitt til gjennom demokratiske prosesser og yrkesetiske verdier.

Et viktig kriterium vil være at vurderingsgrunnlaget oppleves som relevant og rettferdig i forhold til elevenes yrkes- og utdanningsinteresser. Dette kriteriet representerer en særlig utfordring i norsk yrkesutdanning, fordi mange elever ser ut til å oppleve den skolebaserte delen av utdanningen som for generell og 
teoretisk med for liten mulighet til spesialisering i ønsket yrke. Elevene synes ikke at de blir vurdert ut fra helhetlig kompetanse i yrket de ønsker å utdanne seg til, og både lærere og elever opplever dette som urettferdig (Bødker-Lund m.fl., 2017; Hiim, 2013).

Fra et kritisk epistemologisk perspektiv vil det være ønskelig å tolke og presisere mål, oppgaver og vurderingskriterier i samarbeid mellom yrkesfaglærere, elever, instruktører og lærlinger. I en artikkel om vurderingssystemet i finsk yrkesutdanning understreker Räisänen og Räkköläinen (2014) at elevmedvirkning i vurderingen blir ansett som et viktig prinsipp for å styrke elevenes læringsutbytte. Fra et kritisk utgangspunkt vil sentrale prinsipper være at elevene har innflytelse over hva slags oppgaver som skal vurderes, og at oppgavene gir muligheter for selvstendighet og utøvelse av skjønn. Overordnede faglige og sosiale perspektiver på yrkesutøvelsen og yrkesetiske utfordringer vil også utgjøre en vesentlig del av vurderingsgrunnlaget.

Kritiske tilnærminger til utdanning har også vært opptatt av å rette søkelyset mot mulige konflikter mellom samfunnets behov for vurdering, sortering og kontroll av kompetanse på den ene siden og elevens behov for å utvikle sin personlighet og kompetanse ut fra sine individuelle forutsetninger på den andre.

\section{Innvendinger mot et kritisk perspektiv på yrkeskompetanse, læreplaner og vurdering}

Habermas er blitt kritisert for å legge for stor vekt på språklig diskurs, på det verbale og på konsensus. Teorien om kommunikativ handling gir begrenset innsikt i forholdet mellom praktisk erfaring og verbalisert kunnskap. Sett fra et pragmatisk perspektiv kan ulikheter i erfaringsbakgrunn innebære ulike begrepsforståelser. Dette innebærer at det kan være svært ulike oppfatninger knyttet til spørsmål om hva som f.eks. er riktig og rettferdig i en situasjon, og det er ikke uten videre sikkert at det er verken mulig eller hensiktsmessig å komme fram til enighet gjennom samtale (Schaanning, 1992). Sett fra et pragmatisk perspektiv vil felles praktiske erfaringer være en viktig forutsetning for å kunne oppnå en felles forståelse, f.eks. av sentrale vurderingskriterier i et yrke.

\section{Sentrale utfordringer og prinsipper i vurdering av yrkeskompetanse - sammenfattende diskusjon}

Bruken av kompetansebegrepet både i norske styringsdokumenter og i internasjonal forskning på yrkesutdanning søker å gi uttrykk for at yrkeskompetanse er helhetlig og flerdimensjonal, og består av et integrert sett av kunnskaper, ferdigheter og eventuelt holdninger (Koenen m.fl., 2015; Meld. St. 28, 2015-2016). Forskning på yrkesutdanning viser at det gjøres forsøk med å utvikle både utdanning og vurderingsformer som er preget av en oppfatning av 
yrkeskompetanse som helhetlig (Cremers, Wals, Wesslink \& Mulder, 2016; Kairisto-Merkanen, Rasanen, Lehtonen \& Lapalainen, 2012; Rauner, 2007; Rein, 2017; Zitter, Hoeve \& de Bruijn, 2016). Både empirisk forskning og epistemologiske analyser peker likevel mot sterke tradisjoner knyttet til oppsplitting mellom teoretiske og praktiske fag og læringsarenaer som skaper hindringer for helhetlig kompetanseutvikling og vurdering (Gessler, 2017; Louw, 2017; Wahlgren \& Aarkrog, 2012; Young, 2004).

Jeg vil i fortsettelsen oppsummere og diskutere epistemologiske perspektiver på hvordan yrkeskompetanse kan vurderes.

En rasjonalistisk, teknisk oppfatning av yrkeskompetanse har hatt en tendens til å innebære en oppfatning av at forholdet mellom teoretisk kunnskap og praktisk yrkesutøvelse er relativt symmetrisk, og at utøvelse i stor grad handler om å anvende teori (Molander, 1997). Det har også vært en tendens til å verdsette teoretiske kunnskaper høyere en praktiske utøvelsesferdigheter i de formelle utdanningssystemene (Hiim, 2013; Molander, 1997). Yrkeskompetanse blir fra et rasjonalistisk perspektiv på sett og vis oppfattet som en sum av elevenes læringsutbytte fra teoretiske og praktiske fag. Mye tyder imidlertid på at en oppfatning av yrkeskompetanse som en sum av teoretiske kunnskaper og praktiske ferdigheter er for enkel.

Oppsplitting i teoretiske og praktiske fag og læringsarenaer gjør seg på ulike måter gjeldende i svært mange yrkesutdanninger, og problemer som oppstår tyder på at dette er lite hensiktsmessig. Det som blir vurdert på skolen handler ofte i stor grad om teoretiske kunnskaper. Forskning på både norsk og internasjonal yrkesutdanning peker mot at teorien det blir undervist i ofte har begrenset sammenheng med og relevans for yrket elevene ønsker å utdanne seg til (BødkerLund m.fl., 2017; Gessler, 2017; Hiim, 2013; Young, 2004). I den norske yrkesutdanningen skal f.eks. hvert fag i skoledelen av utdanningen vurderes med egen karakter, noe som har en tendens til å hindre fagintegrering, yrkesforankring og integrering av teori og praksis (Bødker-Lund m.fl., 2017; Hiim, 2013).

Eventuell verkstedpraksis på skolen blir i det norske systemet ofte definert som et praktisk fag som skal vurderes med egen tallkarakter, noe som igjen bidrar til å hindre integrering av praksis og teori. Praksisen kan dessuten være preget av relativt oppsplittede, standardiserte øvelser og oppgaver med relativt uklar relevans for yrket eleven ønsker å utdanne seg til, noe som også medfører mangel på yrkesrelevans i vurderingsgrunnlaget (Bødker-Lund m.fl., 2017; Hiim, 2013).

Problemet med vurdering som omhandler separate teoretiske og praktiske fag eller avgrensede standardiserte øvelser er at det som blir målt og vurdert, ikke gir tilstrekkelig uttrykk for yrkeskompetanse, sett fra et mer pragmatisk og kritisk perspektiv. Yrkeskompetanse består ikke av en "sum" av teoretiske skolefagkunnskaper og praktiske øvelsesferdigheter, men av helhetlig, praktisk-teoretisk kompetanse som handler om å kunne tolke, planlegge, gjennomføre, 
teoretisk begrunne, vurdere, kritisere og utvikle sentrale yrkesoppgaver (Dreyfus \& Dreyfus, 1986, 2010; Schøn, 1995). Vurderingsformene kan i seg selv bidra til å hindre utvikling av yrkeskompetanse, fordi de forsterker tendenser til oppsplitting av teori og praksis, og skaper problemer for lærere og elever som ønsker å gjennomføre ulike former for fagintegrering knyttet til autentiske oppgaver og mer helhetlig yrkesopplæring (Sylte, 2014).

Forsøk med å utvikle kompetansebeskrivelser for det enkelte yrke i norsk yrkesutdanning har dels bakgrunn i behov for sammenlikning og måling av yrkeskompetanse og utdanning i forbindelse med markedsliberalisering og globalisering (Larsen, 2013; NOU 2008:18; Utdanningsdirektoratet, 2013). Slike beskrivelser handler om hvilke oppgaver en velkvalifisert yrkesutøver skal kunne utføre, og er blitt utviklet i nært samarbeid med yrkesutøvere. De kan være et skritt mot å styrke sammenhengen mellom yrkesinnhold og utdanningsinnhold og mot å styrke mulighetene for å utvikle og vurdere helhetlig yrkeskompetanse i skoledelen av norsk yrkesutdanning. Dette var også en del av hensikten (Meld. St. 30, 2003-2004). For å oppnå en slik hensikt må imidlertid kompetansebeskrivelsene følges opp av at mål og læringsutbyttebeskrivelser i læreplanene er strukturert omkring autentiske yrkesfunksjoner og -oppgaver, og av at både mål og retningslinjer for vurdering legger vekt på begrunnelse så vel som utøvelse av slike oppgaver.

Læringsutbyttebeskrivelsene i dagens norske læreplaner ble etter reformen Kunnskapsløftet (Utdanningsdirektoratet, 2006) delvis, om enn ikke fullt ut, strukturert omkring yrkesfunksjoner, noe som kan oppfattes som et framskritt i forhold til å styrke muligheter for helhetlig vurdering. På grunn av den store bredden av yrker som inngår i det enkelte utdanningsprogram, særlig i det første året, er imidlertid beskrivelsene så generelle at de likevel har hatt begrenset betydning. Det har også vært eksempler på at sluttvurdering av elevene etter de to første skolebaserte årene er blitt basert på skriftlige casebeskrivelser av yrkesutfordringer som primært skal løses og besvares på papiret. Sett fra et pragmatisk perspektiv kan ikke yrkeskompetanse reduseres til ord og skriftlighet uten at man taper vesentlige aspekter som bare kan uttrykkes gjennom handling og selvstendig, profesjonell dømmekraft i realistiske praktiske situasjoner. Det som blir målt og vurdert gjennom skriftlige caseoppgaver er derfor ikke tilstrekkelig egnet til å uttrykke elevers begynnende, helhetlige yrkeskompetanse.

Kompetansebeskrivelser av yrkene og kompetansebaserte læringsutbyttebeskrivelser kan også i seg selv medføre en tendens til standardisering. Utgangspunktet er en ide om at det er mulig å gi uttømmende verbale beskrivelser av yrkeskompetanse på ulike nivå, som så kan gi grunnlag for objektiv måling. Sett fra et pragmatisk perspektiv vil det være problematisk å utforme slike beskrivelser, fordi det kan være så mange ulike måter å utøve et yrke på. Ordene vil heller ikke kunne romme ferdighetsmessige og tause sider ved kompetansen. Muligheten for å forstå kompetansebeskrivelser som omhandler det enkelte yrke vil 
dessuten være avhengig av profesjonell yrkeserfaring hos den som skal tolke dem. Det kan være vanskelig for elever å forstå innholdet i kompetansebeskrivelsene. Det kan dessuten argumenteres for at muligheten for ulike tolkninger er så stor at forsøk på objektive målinger blir upålitelige. Det er viktig å være klar over disse begrensningene. Beskrivelser av kjerneoppgaver og kompetansebehov i et yrke kan likevel bidra til at søkelyset blir rettet mot relevansen av utdanningsinnhold og vurderingskriterier i forhold til yrkesinnholdet, noe som er svært vesentlig.

Tendenser til å benytte relativt standardiserte praktiske øvelser som grunnlag for vurdering av yrkeskompetanse finner vi også i sertifiseringskurs og noen former for fagprøver. Hensikten med standardiserte øvelser og oppgaver et at de skal være enkle både å gjennomføre og vurdere, fordi de også har standardiserte løsninger. Fra et pragmatisk og kritisk perspektiv blir det framhevet at standardiserte oppgaver og løsninger ikke representerer realistisk profesjonell yrkesutøvelse på høyt nivå (Dreyfus \& Dreyfus, 1986; Nielsen m.fl., 2010). Helhetsperspektivet på yrket går tapt, og elevenes evne til selvstendig å definere utfordringer og gjennomføre situasjonstilpassede løsninger kan bli skadelidende. Det som måles er elevens eller lærlingens evne til å reprodusere rutinestyrt, forenklet arbeid.

I den nye reformen for yrkesutdanning som nå iverksettes i Norge, er det lagt vekt på å redusere bredden av yrker i hvert utdanningsprogram. Hensikten er å gjøre utdanningen mindre generell og styrke elevenes muligheter for å spesialisere seg i yrket de ønsker å utdanne seg til. Sammenhengen mellom læringsarenaer og fag skal bli bedre gjennom økt samarbeid mellom skole og arbeidsliv og styrket yrkesforankring av skolefagene (Meld. St. 20, 2012-2013; Meld. St. 28, 2015-2016). Flere signaler peker dermed mot at elevenes muligheter for å utvikle og bli vurdert på grunnlag av helhetlig yrkeskompetanse skal styrkes. Signalene er imidlertid motstridende. Mye tyder på at utfordringer i den norske yrkesutdanningen som er nevnt i denne artikkelen fortsatt vil gjøre seg gjeldende. Hovedstrukturen er fortsatt to år i skole pluss to år i bedrift, selv om det blir lagt vekt på at elevene så langt mulig skal ha arbeidspraksis i bedrift gjennom de første to årene. Selv om sentrale grunnlagsdokumenter som nevnt innledningsvis gir uttrykk for et helhetlig kompetansebegrep (Meld. St. 28, 2015-2016), så peker andre utdanningsdokumenter mot oppsplitting mellom kunnskaper og ferdigheter.

Et eksempel gjelder retningslinjer for yrkes- og profesjonsutdanning på universitetsnivå. Meld. St. 16 (2016-2017, vedlegg 3) inneholder det som blir kalt et nasjonalt kvalifikasjonsrammeverk som angir maler for læringsutbyttebeskrivelser på ulike nivå i høyere utdanning, inkludert høyere yrkes- og profesjonsutdanning. Kvalifikasjonsrammeverket har klare fellestrekk med den rasjonalistiske mål-middel-pedagogikken og taksonomisystemene som ble utviklet i USA på 1950-tallet (Tyler, 1950). Malene for læringsutbyttebeskrivelser er inndelt i 
henholdsvis kunnskaper, ferdigheter og generell kompetanse. Det siste omhandler i relativt stor grad sosial kompetanse og evne til etisk vurdering, og kunne nok tidligere inngått i kategorien verdier og holdninger. Malene for ulike nivå på kunnskaper og ferdigheter har fellestrekk med Blooms (1956) taksonomi-systemer, som var rettet mot operasjonalisering, måling og kontroll av læringsresultater. Det er en fare for at taksonomi-inndelingen i seg selv bidrar til at forholdet mellom kunnskaper, ferdigheter og etisk vurdering blir preget av splittelse, snarere enn av helhet og sammenheng. Begrepsinndelingen og nivåtenkningen som kommer til uttrykk er problematisk sett ut fra en pragmatisk og kritisk oppfatning av å vurdere helhetlig yrkeskunnskap.

Fra et pragmatisk perspektiv er det et grunnprinsipp at yrkeskompetanse blir utviklet og vurdert i daglige, praktiske kontekster. Både oppgaver som vurderes underveis og oppgaver som velges ut til formell sluttvurdering må primært være en form for helhetlige eksempeloppgaver som er egnet til å stimulere og vise elevens evne til å definere, planlegge, praktisk gjennomføre, beskrive, teoretisk begrunne, vurdere og kritisere sentrale oppgaver i yrket. Det er viktig at oppgavene gir elevene muligheter for å involvere seg og til å utvise selvstendig dømmekraft. En form for praktisk-teoretisk fag/svenneprøve som ivaretar disse prinsippene vil være hensiktsmessig for å uttrykke og vurdere elevenes yrkeskompetanse. Skriftlig dokumentasjon kan med fordel suppleres av bilder og film som viser arbeidsprosessen. Vurdering i form av karakterer bør ut fra prinsipper som er diskutert ovenfor ikke være for fingradert, fordi det er vanskelig å fingradere profesjonell yrkeskompetanse.

Sett fra et kritisk perspektiv utgjør sosial kompetanse en grunnleggende side ved yrkeskompetansen. Den er basert på kulturelle og etiske verdier og normer og vår evne til å samhandle med andre mennesker. Sosial kompetanse må vektlegges både i læreprosessen og i vurderingen gjennom oppgaver som handler om samarbeid og om utøvelse av yrkesetisk skjønn. Også fra et kritisk utgangspunkt vil en framheve viktigheten av å begrense bruken av graderte målinger i vurderingen. Vurderingen i fag- og yrkesopplæring skal på den ene siden sikre samfunnets behov for yrkesutøvere som kan utføre arbeidet på en fagmessig og etisk forsvarlig måte. På den annen side skal den ikke bidra til en unødig objektivisering og tingliggjøring av elevene (Illeris, 2007).

\section{$\AA$ A vurdere yrkeskunnskap - konklusjon}

Epistemologiske analyser viser at det er mange utfordringer knyttet til å fremme og uttrykke yrkeskompetanse, som er vurderingens formål i yrkesutdanning sett ut fra den norske opplæringsloven. Satt på spissen kan det stilles spørsmål ved om det er yrkeskompetanse som blir utviklet og vurdert, eller om det er mer fragmentariske teoretiske kunnskaper, skriveferdigheter eller ferdigheter i å utføre relativt enkle, standardiserte øvelser og oppgaver. Oppmerksomheten i det 
norske utdanningssystemet i de siste årene kan kanskje sies å ha vært vel så mye rettet mot det å måle læringsresultater som mot hva som blir målt og vurdert.

Det er behov for et langt sterkere søkelys på ulike epistemologiske dimensjoner i yrkeskompetanse, og på det yrkesfaglige innholdet i vurderingen. Uten en nyansert forståelse av yrkeskompetanse risikerer vi at vurderingssystemet dels bidrar til å svekke, snarere enn å fremme, både elevenes motivasjon, deres kompetanseutvikling og kvaliteten på yrkesutdanningen.

\section{Om forfatteren}

Hilde Hiim er professor ved OsloMet - Storbyuniversitetet, fakultet for lærerutdanning og internasjonale studier, hvor hun underviser på master- og Ph.D.nivå. Hennes interessefelt er yrkes- og profesjonsutdanning, yrkespedagogikk og yrkesdidaktikk. Hun har gitt ut en rekke bøker og artikler på dette feltet, og har ledet flere større forskningsprosjekter. Hun arbeider nå med et forskningsprosjekt om relevant yrkesutdanning og yrkesfaglærerutdanning gjennom samarbeid skole/arbeidsliv. 


\section{Referenser}

Aakernes, N. (2018). From school to work: Coherence between learning in school and learning in workplaces for apprentices in the Media graphics programme in Norway. Nordic Journal of Vocational Education and Training, 8(1), 76-97.

Billett, S. (2011). Vocational education: Purposes, traditions and prospects. Dordrecht: Springer.

Bloom, B.S., Engelhart, M.D., Furst, E.J., Hill, W.H. \& Krathwohl, D.R. (1956). Taxonomy of educational objectives: The classification of educational goals. Handbook I: Cognitive domain. New York: David McKay Company.

Bottery, M. (2006). Education and globalization: Redefining the role of the educational professional. Education Review, 58(1), 95-113.

Bødtker-Lund, D., Hansen, K.H., Haaland, G. \& Vagle, I. (2017). Endringsbehov i norsk yrkesopplæring? - Elevers, lærlingers og yrkesfaglæreres erfaringer med yrkesopplæring i Vg1. Scandinavian Journal of Vocations in Development, 2, $1-33$.

Cremers, P.H.M., Wals, A.E.J., Wesselink, R. \& Mulder, M. (2016). Design principles for hybrid learning configurations at the interface between school and workplace. Learning Environments Research, 19, 309-334.

Davies, B. \& Bansel, P. (2007). Neoliberalism and education. International Journal of Qualitative studies in Education 20(3), 247-259.

Dreyfus, H. (1991). Being-in-the-world: A commentary on Heidegger's Being and time, division 1. Cambridge, Massachusetts, London: The MIT Press.

Dreyfus, H. \& Dreyfus, S. (1986). Mind over machine: The power of human intuition and expertice in the era of the computer. New York: Free Press.

Gessler, M. (2017). The lack of collaboration between companies and schools in the German dual apprenticeship system: Historical background and recent data. International Journal for Research in Vocational Education and Training, 4(2), 164-195.

Habermas, J. (1999). Kommunikativ handling, lov og rett. Oslo: Tano Aschehoug.

Habermas, J. (1980). Teorier om samfund og sprog. København: Gyldendal.

Heidegger, M. (1978). Being and time. Oxford: Blackwell.

Heusdens, W.T., Bakker, A., Baartman, L.K.J. \& de Bruijn, E. (2016). Contextualising vocational knowledge: A theoretical framework and illustrations from culinary education. Vocations and Learning, 9(2), 151-165.

Hiim, H. (2015). Kvalitet i yrkesutdanningen: Resultater fra et aksjonsforskningsprosjekt om yrkesutdanningens innhold og struktur. Norsk Pedagogisk Tidsskrift, 99(2), 136-148.

Hiim, H. (2013). Praksisbasert yrkesutdanning: Hvordan utvikle relevant utdanning for skole og arbeidsliv. Oslo: Gyldendal Akademisk.

Hiim, H. (2010). Pedagogisk aksjonsforskning: Tilnærminger, eksempler og kunnkapsfilosofisk grunnlag. Oslo: Gyldendal Akademisk. 
Hiim, H. \& Hippe, E. (2001). Å utdanne profesjonelle yrkesutøvere: Yrkesdidaktikk og yrkeskunnskap. Oslo: Gyldendal Akademisk.

Illeris, K. (2007). How we learn: Learning and non-learning in school and beyond. Abingdon: Routledge.

Janik, A. (1996). Kunskapsbegreppet i praktisk filosofi. Stockholm: Symposion.

Johansson, M.W. \& Thång, P.O. (2017). Bedömning för yrkeslärande. I A. Fejes, V. Lindberg \& G.-B.Wärwik (Red.), Yrkesdidaktikens mångfald (s. 189-204). Stockholm: Lärarförlaget.

Josefsson, I. (1991). Kunnskapens former: Det reflekterande yrkeskunnandet. Stockholm: Carlsons.

Kairisto-Mertanen, L., Räsänen, M., Lehtonen, J. \& Lappalainen, H. (2012). Innovation pedagogy - learning through active multidisciplinary methods. Revista de Docencia Universitaria, 10(1), 67-86.

Koenen, A.-K., Dochy, F. \& Berghmans, I. (2015). A phenomenographic analysis of the implementation of competence-based education in higher education. $\mathrm{Te}-$ aching and Teacher Education, 50, 1-12.

Larsen, S.H. (2013). NHOs perspektiv - kan ECVET svare til bedriftenes behov? Foredrag på Utdanningsdirektoratets Oppstartseminar for nasjonalt arbeid med ECVET, 3. juni 2013.

Lester, S. \& Religa, J. (2017). "Competence" and occupational standards: observations from six European countries. Education + Training, 59(2), 201-214.

Louw, A. (2017). Kobling mellem skole og praktik på erhvervsuddannelserne. I K.E. Andreassen \& H. Duch (Red.), Forandringer i ungdomsuddannelserne: Overgange og indsatser (s. 93-114). Aalborg: Aalborg Universitetsforlag. Ungdomsliv.

Meld. St. 9. (2016-2017). Fagfolk for fremtiden: Fagskoleutdanning. Oslo: Kunnskapsdepartementet.

Meld. St. 16. (2016-2017). Kultur for kvalitet i høyere utdanning. Oslo: Kunnskapsdepartementet.

Meld. St. 20. (2012-2013). På rett vei: Kvalitet og mangfold i fellesskolen. Oslo: Kunnskapsdepartementet.

Meld. St. 28. (2015-2016). Fag - Fordypning - Forståelse: En fornyelse av Kunnskapsløftet. Oslo: Kunnskapsdepartementet.

Meld. St. 30. (2003-2004). Kultur for læring. Oslo: Kunnskapsdepartementet.

Molander, B. (1997). Arbetets kunskapsteori. Stockholm: Gotab.

Nielsen, L.D., Nielsen, K.A., Munk-Madsen, E. \& Hartmann-Petersen, K. (2010). Fleksibilitet, flygtighet og frirum: En kritisk diagnose af det senmoderne arbejdsliv. Frederiksberg: Roskilde Universitetsforlag.

NOU 2008:18. Fagopplæring for framtida. Oslo: Kunnskapsdepartementet.

Räisänen, A. \& Räkköläinen, M. (2014) Assessment of learning outcomes in

Finnish vocational education and training. Assessment in Education: Principles, Policy \& Practice, 21(1), 109-124. 
Rauner, F. (2007). Practical knowledge and occupational competence. European Journal of Vocational Training, 40(1), 52-66.

Rein, V. (2017). Towards the compatibility of professional and scientific learning outcomes: Insights and options in the context of competence orientation. International Journal for Research in Vocational Education and Training, 4(4), 325-345.

Schaanning, E. (1992). Blindflekker i Habermas' kommunikasjonsteori. Materialisten, 1-2/1992.

Schøn, D. (1983). The reflective practitioner. New York: Basic books.

Schøn, D. (1988). Educating the reflective practitioner. San Fransisco: Jossey Bass.

Schøn, D. (1995). Knowing-in-action. The new scholarship requires a new epistemology. Change, 27(6), 27-34.

Sennett, R. (2008). The craftsman. New Haven: Yale University Press.

Stenhouse, L (1975). An introduction to curriculum research and development. London: Guilford.

Stenhouse, L. (1983). Authority, education and emancipation. London: Heineman.

Sylte, A.L. (2014). Vurdering for yrkesrelevant opplæring. Nordic Journal of Vocational Education and Training, 4, 1-18.

Tyler, R. (1950). Undervisningsplanlægning. København: Eijler.

Utdanningsdirektoratet. (2006). Læreplanverket for Kunnskapsløftet. Oslo: Utdanningsdirektoratet.

Utdanningsdirektoratet. (2013). Kvalitet i fagopplæringen: Kvalitetsvurderingssystem for fag-og yrkesopplæringen. Oslo: Utdanningsdirektoratet.

Wahlgren, B. \& Aarkrog, V. (2012). Transfer: Kompetence i en professionel sammenhæng. Aarhus: Aarhus Universitetsforlag.

Wittgenstein, L. (2003). Filosofiske undersøkelser. Oslo: De norske bokklubbene.

Young, M. (2004). Conceptualizing vocational knowledge: Some theoretical considerations. I H. Rainbird, A. Fuller \& A. Munro (Red.), Workplace learning in context (s. 186-200). London: Routledge.

Young, M. (2007). Qualification frameworks: Some conceptual issues. European Journal of Education, 42(4), 445-457.

Zitter, I., Hoeve, A. \& de Bruijn, E. (2016). A design perspective on the schoolwork boundary: A hybrid curriculum model. Vocations and Learning, 9(1), 111131. 